\title{
Reference Correction: Preliminary Evaluation of a Web-Based Psychological Screening Tool in Adolescents Undergoing Minimally Invasive Pectus Surgery: Single-Center Observational Cohort Study
}

Davina Wildemeersch, MD; Lisa Bernaerts, MA; Michiel D'Hondt, MD; Guy Hans, MD, PhD

Antwerp University Hospital, Edegem, Belgium

\section{Corresponding Author:}

Davina Wildemeersch, MD

Antwerp University Hospital

Wilrijkstraat 10

Edegem,

Belgium

Phone: 3238213586

Email: davina.wildemeersch@uza.be

\section{Related Article:}

Correction of: https://mental.jmir.org/2018/2/e45/

(JMIR Ment Health 2018;5(4):e11608) doi: 10.2196/11608

The authors of "Preliminary Evaluation of a Web-Based Psychological Screening Tool in Adolescents Undergoing Minimally Invasive Pectus Surgery: Single-Center Observational Cohort Study" (JMIR Ment Health 2018;5(2):e45) made two errors in the References section.

Rather than Rugo et al (2010), reference 6 should be as follows:

Brammer Jacobsen E, Thastum M, Jeppesen JH, Pilegaard HK. Health related quality of life in children and adolescents undergoing surgery for pectus excavatum. Eur J Pediatr Surg 2010;20:85-91.

Rather than Vigna et al (2006), reference 51 should be as follows:
Fan, X, Miller, BC, Park, K, Winward, BW, Christensen, M, Grotevant, HD, Tai, RH. An exploratory study about inaccuracy and invalidity in adolescent self-report surveys. Field Methods. 2006;18(3), 223-244.

The correction will appear in the online version of the paper on the JMIR website on November 12, 2018, together with the publication of this correction notice. Because this was made after submission to PubMed, PubMed Central, and other full-text repositories, the corrected article also has been resubmitted to those repositories.

\section{References}

6. Jacobsen EB, Thastum M, Jeppesen JH, Pilegaard HK. Health-related quality of life in children and adolescents undergoing surgery for pectus excavatum. Eur J Pediatr Surg 2010 Mar;20(2):85-91. [doi: 10.1055/s-0029-1243621] [Medline: 20112187]

51. Fan X, Miller, Park K, Winward B, Christensen M, Grotevant H, et al. An Exploratory Study about Inaccuracy and Invalidity in Adolescent Self-Report Surveys. Field Methods 2016 Jul 21;18(3):223-244. [doi: 10.1177/152822X06289161]

Edited by G Eysenbach; this is a non-peer-reviewed article. Submitted 17.07.18; accepted 24.08.18; published 12.11.18.

Please cite as:

Wildemeersch D, Bernaerts L, D’Hondt M, Hans $G$

Reference Correction: Preliminary Evaluation of a Web-Based Psychological Screening Tool in Adolescents Undergoing Minimally

Invasive Pectus Surgery: Single-Center Observational Cohort Study

JMIR Ment Health 2018;5(4):e11608

URL: https://mental.jmir.org/2018/4/e11608/

doi: $\underline{10.2196 / 11608}$

PMID: $\underline{30578210}$ 
CDavina Wildemeersch, Lisa Bernaerts, Michiel D’Hondt, Guy Hans. Originally published in JMIR Mental Health (http://mental.jmir.org), 12.11.2018. This is an open-access article distributed under the terms of the Creative Commons Attribution License (https://creativecommons.org/licenses/by/4.0/), which permits unrestricted use, distribution, and reproduction in any medium, provided the original work, first published in JMIR Mental Health, is properly cited. The complete bibliographic information, a link to the original publication on http://mental.jmir.org/, as well as this copyright and license information must be included. 